\section{CHARACTERISING TURKISH DESIGN THROUGH GOOD DESIGN CRITERIA: THE CASE OF `DESIGN TURKEY’ INDUSTRIAL DESIGN AWARDS}

\author{
Gülay HASDOĞAN
}

Received: 12.10.2011; Final Text: 27.03.2012

Keywords: good design awards; Turkish design; Design in Turkey; industrial design evaluation criteria.
'Good design' awards are used as an effective tool to promote a country's products in the global market. They aim to raise society's and industry's awareness about well qualified product designs by presenting their merits. In this way, award-winning designs can be a good indicator of a country's ideals, qualities and characteristics of design. Design Turkey Industrial Design Awards is a state- supported biannual national award scheme, which was first organised in 2008. The author of this article directed the development of the award scheme by consulting the opinions of experts, scholars and professionals from the industrial design community in Turkey and coordinated the evaluation process. This article aims to explore the characteristics of winning product designs of Design Turkey Industrial Design Awards, through the evaluation criteria of the award scheme. The article begins with making a general overview of the origin and development of the 'good design' concept, especially within the scope of world-known Industrial Design Awards. Later, the development process for the Design Turkey Awards evaluation criteria is explained, with reference to opinions of the Turkish industrial design community. The application statements of award-winning designs, along with jurors' evaluation comments in response to various design criteria are analysed. The characteristics of award-winning designs are then defined through good design criteria. Finally, the extent to which the strengths of awarded designs match with the ideals of the Turkish industrial design community is discussed.

\section{INTRODUCTION}

Good design awards aim to promote notable qualities of product designs in order to raise society's and industry's awareness about well qualified designs. They are generally used as an effective tool to promote a country's products in the global market. Partly for this reason, widely known international design awards are first established on a national basis, and 
only later became international. Examples include iF Design Awards and Red Dot Design Awards of Germany, Japanese Good Design Awards, Industrial Design Excellence Awards (IDEA) of the United States and Australian International Design Awards (Sung et al., 2009). Most of these schemes were established as an activity of their national or regional promotional bodies. Therefore award-winning designs can be an indicator of a country's ideals, qualities and characteristics of design.

Design Turkey Industrial Design Awards is a biannual national evaluation scheme, which was first organised in 2008 and repeated in 2010, having the aim "to make visible the benefits that good design brings to society and industry in Turkey, by rewarding good product design that is respectful to user needs, and which provides added value and competitive advantage" (Hasdoğan et.al., 2012). The evaluation criteria of the scheme were determined by consulting the opinions of an advisory committee formed of experts, scholars and professionals in the industrial design field in Turkey. The author of this article coordinated the development and the evaluation process of the award scheme.

This paper aims to analyse the qualities of Turkish industrial design, through the application statements and evaluations made for the winning product designs of the Design Turkey Industrial Design Awards. It will also make a comparison between the initial opinions of the advisory committee concerning recommended evaluation criteria, and the extent to which these criteria were fulfilled by award-winning designs. The answers to the following questions will be sought:

- What are the expectations of the Turkish industrial design community from 'good design'? What do they value most in terms of design criteria?

- Which strategies do the applicants of Design Turkey award-winning products follow to create powerful designs? How do they describe the strengths of their designs?

- Which qualities of products submitted to Design Turkey do assessors value? Which product types stand out in terms of certain design criteria?

- To what extent do the design criteria expectations of the Turkish design community match with the qualities of winning designs?

The paper will begin by making a general overview of the origin and development of the 'good design award' concept, especially within the scope of world-known industrial design awards. Later, the aims, drivers and development process of the Design Turkey Industrial Design Award scheme will be explained. Answers to the above questions will be sought by analysing applicants' product statements and jurors' evaluations in the Design Turkey Awards database (Design Turkey Intranet, 2011).

\section{ORIGIN AND DEVELOPMENT OF GOOD DESIGN AWARDS}

The term 'good design' started to be used after the Second World War, in order to oppose unnecessary styling as a means to increase sales, and was characterised generally by an emphasis on pure form rather than decoration (Woodham, 2004). The roots of promoting good design via award schemes can be traced back to the foundation of the Council of Industrial Design (CoID) in 1944 in the United Kingdom. CoID's objective 
was to encourage and assist British industry to design new products for world markets. The rationale was that by defining and promoting 'good design', public awareness about good taste would be increased, a home market for good modern design would be created and thus British manufacturers would be encouraged to make modern products that would also sell abroad (Burral, 1997). CoID organised the 'Britain Can Make It' exhibition in 1946 with this aim. As Hayward (1998) depicted, the exhibition held a Design Quiz that gave visitors the chance to involve themselves with the precepts of 'good design'. The questions in the quiz were based on three fundamental design criteria: (1) efficiency (does it do its job well?), (2) sound construction (is it well made?), and (3) attractiveness (does it look well?). According to Hayward, this is an accessible, non-technical language that draws its authority from everyday experience, which is largely a matter of common sense. It is based on an assumption that meanings and aesthetic standards are common and universal at any one time. In the booklet of the Festival of Britain, which was organised in 1951 by CoID, Gordon Russell emphasized that design should be recognised as not only good workmanship and material, but an integral part of quality (Lucie-Smith, 1983, 114).

A series of good design exhibitions were organised at Museum of Modern Art in the US from 1950 to 1955, which intended to help educate the consumer to be able to make discriminating choices about products (Sparke, 2004). The exhibitions contained many objects that endorsed European modernist aesthetics (Woodham, 2004).

The principles of today's best known international design awards are also influenced by the good design movement during the same time period. The origin of iF Design Awards can be traced back to the annual 'special show' held at the Hannover Messe, first organised in 1953 and later named 'the good industrial form'. Its jury consisted of a constantly changing group of designers, artists and industrialists as well as 'experts' with special skills. Its concern was to support functional design, focused on the essentials and viewed ornamentation as a true crime (iF Design Awards, 2011). The Red Dot Design Awards has its roots in the 'permanent exhibition of elegant industrial products' created in 1955 jointly by the Krupp Corporation and Haus Industrieform (later developed under the name Design Zentrum Nordrhein Westfalen) (Red Dot Website, 2011). CoID established the Design Center Award Scheme in 1957, with a parallel approach to The Italian Compasso D'Oro Awards, which had been established earlier in 1954 (Woodham, 2004).

The Japanese Good Design Awards was established in 1957 under the name 'Good Design Selection System', with an aim to stimulate the creation of products with a high level of originality in order to overcome the problem of copied merchandise. In 1963 the system was opened to general submissions, in order to encourage exports with an emphasis on thoroughness of manufacture through design instead of originality (Good Design Award, 2008).

The British CoID and its promotion of 'good design' also had an impact on design promotion in Australia. The Industrial Design Council of Australia established its Good Design Label in 1960, which sought to recognize and award design excellence and innovation, to improve standards of design in industry, to promote the benefits of design to the public, and to foster innovation (Woodham, 2004). 
Kaygan (2006) defines two sets of criteria to evaluate products in the industrial design field. The first is for designerly evaluation, in circulation among designers in practice or within academies, and which also is the basis of 'good design discourse'. The second is facilitated in the production of design products for consumption, such as 'market success'. The good design movement had an aim to impose on society the notion of 'good taste' on the basis of modern design, which is purified by eliminating ornamentation. This approach lost its power through time, since the second set of criteria favoured public taste that manufacturers increasingly turned to. Pop art in the 1960s, and the modernistic revival in the 1970s, involved rejection of good design standards, which had been valid up until that point (Lucie-Smith, 1983, 115). With the postmodernist movement, earlier idealistic links with modernism and design were broken and a more pragmatic, market oriented, popular approach was embraced giving an equal voice to different social and cultural groupings (Sparke, 2004). The British Design Council's whole selection process was closed in the late 1980s because the selected design exemplars could not align with public taste and failed to create instant commercial success in the local market. CoID could not persuade manufacturers to invest in good design (Burral, 1997). According to Buchanan (2000), the good design exhibitions in MOMA represented the tastes and preferences of a relatively small, elite social group, promoting standards that were too narrow. The product was judged in isolation from the immediate situation of use. The focus was on form, function, materials and the manner of industrial production and ignoring the content and context of the product.

Through this transition process from modernism to postmodernism, early definitions of good design changed. Although the British Design Council's good design selection system was terminated, other award schemes such as iF, Red Dot, Australian International Design Awards and the Japanese G-mark were sustained and became international. They became facilitators of competition between companies. By the influence of information technologies, the nature of product design practice also changed. Designers began to explore 'user experience' and employ insights from social and behavioural sciences (Buchanan, 2000). New criteria such as 'user friendliness' and 'environmental friendliness' were introduced to most of the schemes.

In Turkey, although industrial design education started in early 1970's, state support for design promotion activities could not be received until the late 2000's (Hasdoğan, 2009). The first examples of promotional activities for industrial design were carried out by the Industrial Designers' Society of Turkey (ETMK), which is the only professional society representing industrial design in Turkey, founded as a non-governmental organisation in 1988. The first industrial design exhibition, 'Designers' Odyssey '94' was organised by ETMK in 1994. More than 100 products by 33 designers participated in the exhibition, which took place in Ankara (ETMK, 2008). ETMK awards were given to the exhibited designs by a jury, which comprised well-known scholars and designers. ETMK repeated the Designers' Odyssey exhibition and awards in 1998 in İstanbul. A succession of exhibitions were then organised by ETMK in 2003, 2005 and 2006 in collaboration with the Turkish Exporters Assembly (TIM). By the TIM's presence, greater emphasis was placed on marketing and exports, and awards were issued in relation to the scope of the exhibitions. In all of these events, the focus was the exhibition itself and the awards were given to the exhibited designs. No subcategories were used in evaluating the designs 
according to product classes and the evaluation criteria were not handled systematically. The events were advertised within the design community and the participants were mainly designers. The exhibitions lacked the necessary attention from Turkish industry.

ETMK aimed to create a more prestigious nationwide award scheme in which the focus would be the award itself rather than the exhibition, whilst the evaluation would be held in a more systematic manner. In 2006, ETMK prepared the groundwork of the award scheme by consulting the opinions of experts in the Turkish design community, and brought the proposal to TIM. TIM took the project proposal to the Undersecretariat for Foreign Trade of the Prime Ministry (DTM), later changed to the Republic of Turkey Ministry of Economy. In February 2008, DTM accepted the project formally and integrated it within its state aided branding programme, TURQUALITY, in partnership with ETMK and TIM. For the first time, a state organisation was involved as a partner in an industrial design event. The award scheme, which was first implemented in 2008, provided an online application and systematic evaluation process organized according to 12 product categories. Nearly 400 entries were received, of which 293 passed the pre-evaluation stage and were exhibited and evaluated by an international jury of 29 experts in an old warehouse (Antrepo) in İstanbul in October 2008. 54 of the products received a Design Turkey Award. The product design exhibition was accompanied by a Conceptual Design Awards exhibition and an international conference. The biannual scheme was organised for the second time in December 2010 and was publicised with an exhibition which took place in the Foreign Trade Complex (where TIM is located) in İstanbul. A total of 311 entries were received for the award scheme in 2010. Of these, 230 entries were exhibited and 66 product design awards were presented. The award scheme received endorsement from the International Council of Societies of Industrial Design (ICSID) in both 2008 and 2010.

\section{EXPECTATIONS OF THE TURKISH DESIGN COMMUNITY CONCERNING 'GOOD DESIGN'}

In October 2006, ETMK announced to its members its intention to design and implement a national industrial design award scheme, in order to raise design awareness and increase the demand for 'good design' in Turkish industry and society (Hasdoğan, 2006). ETMK consulted the opinions of an advisory group formed of professional designers, design academicians and interdisciplinary experts, about the aim, application rules, evaluation criteria, product classifications and awarding process of such an award scheme. 70 experts from the advisory group responded to the enquiry, consisting of five questionnaires sent through electronic mail and a live meeting.

In the first questionnaire, advisory committee members were first asked to consider the stakeholders of a product within its whole life cycle and to prioritise them on the basis of which stakeholders' needs 'good design' should respond to. 'The user', 'the producer' and 'the marketer' were given as example stakeholders. Out of 34 respondents, 25 placed the user in first place; six gave highest priority to the producer and one to the marketer (ETMK, 2006). A common opinion among the respondents who gave the first place to the user was that a product, which satisfies the user, would also satisfy the producer and the marketer. Few respondents declared that the user is often disregarded in the product development process. 
Apart from these three stakeholders, 'the designer', 'the society' and 'the environment' were also considered as stakeholders in the product life cycle.

Two subsequent questions to the advisory committee members requested examples to the needs of these stakeholders and to list the values and qualities that 'good design' should bring forward if the long-term benefits to society, the environment and the national economy were to be taken into account. The answers to both questions were used to identify evaluation criteria (ETMK, 2007). The frequency of mentioned concepts is given in Table 1 . The concepts were grouped under eight headings referring to evaluation criteria:

1. Novelty and Innovation: concepts related to novelty and innovation were generally mentioned in relation to the user's and marketer's needs and long-term macro-level benefits. The most frequently mentioned concepts were originality, novelty, innovation, distinctiveness, differentiation from competitors, adding user value to technological innovation, creativity and originality in problem identification and solution.

2. Functionality: was mainly mentioned in relation to the needs of the user. It was qualified with concepts such as usefulness and performing the offered function without introducing any problem.

3. Aesthetics: was most frequently mentioned in relation to the user's needs. It was described with qualities such as attractiveness, raising society's taste, contemporary, evoking curiosity, offering aesthetical pleasure and having visual unity.

4. Sensitivity to Users: was the most frequently mentioned concept. The related concepts were mainly tied to the user's needs and long-term benefits. The concepts included under this category were: ease of use, easy to understand, making the user's life easier, healthy, safe, reliable (high quality and durable), building an emotional tie with the user, encouraging interaction, accessibility by everyone, empowering the user (making the user productive and independent), honest (communicating the function and value truly), and good value for money.

5. Production Quality and Producability: was the second most frequently referred concept. It was mainly referred to in relation to the needs of the producer. Related concepts were: choosing the right materials and processes, having a high profit margin, high quality production, creating economic value, and conforming with standards.

6. Contribution to Brand and Potential for Competition: was mainly referred to in relation to the needs of the marketer. Related concepts were: contribution to brand awareness, developing brand identity, having high market share and sales success, creating export potential, trendsetting, being parallel to current trends, and suitability to the target group.

7. Sensitivity to Society: was mainly mentioned in relation to longterm benefits to society. Related concepts were: offering cultural content, and good usage of national resources.

8. Respect to Environment: was mainly mentioned in relation to the long-term benefits to society and the environment. Related concepts 


\begin{tabular}{|l|l|l|l|l|l|l|}
\hline $\begin{array}{l}\text { Mentioned criteria / needs of } \\
\text { stakeholders and long-term benefits }\end{array}$ & User's needs & $\begin{array}{l}\text { Producer's } \\
\text { needs }\end{array}$ & $\begin{array}{l}\text { Marketer's } \\
\text { needs }\end{array}$ & $\begin{array}{l}\text { Long-term } \\
\text { benefits }\end{array}$ & Other & Total \\
\hline Novelty and innovation & 10 & 3 & 8 & 12 & & 33 \\
\hline Functionality & 12 & 1 & & 3 & & 16 \\
\hline Aesthetics & 10 & & 2 & 5 & 1 & 18 \\
\hline Sensitivity to users & 47 & 1 & 2 & 36 & & 86 \\
\hline $\begin{array}{l}\text { Production quality and } \\
\text { producability }\end{array}$ & & 53 & & 15 & & 68 \\
\hline $\begin{array}{l}\text { Contribution to brand and potential } \\
\text { for competition }\end{array}$ & 5 & 11 & 26 & 6 & & 48 \\
\hline Sensitivity to society & 1 & & 1 & 13 & 2 & 17 \\
\hline Respect to environment & 5 & 2 & & 28 & 13 & 48 \\
\hline Total & 90 & 71 & 39 & 118 & 16 & \\
\hline
\end{tabular}

Table 1. Frequency of mentioned concepts in relation to stakeholders' needs and long-term benefits to society, the national economy and the environment. were: long usage life, energy saving, raising the user's awareness about the rate of energy consumption, economic usage of natural resources, reuse, and minimising the harm to the environment during production, usage and disposal.

9. For the second questionnaire, the advisory committee members were provided with a list of the above eight criteria and underlying concepts, and were then asked three questions to try to create a hierarchy between the criteria:

1. Which criteria must a 'good design' fulfill?

2. Which criteria render a product superior to other products?

3. Which criteria should not be taken into account when evaluating 'good design'?

These questions formed the basis of divisions between the 'good design award' and 'superior design award' in the Design Turkey awards scheme.

The most frequently mentioned criteria for the musts of good design were related to sensitivity to the user. Concepts such as ease of use, safety, health, ease of understanding, making the user's life easier, honesty, reliability, and encouraging interaction were mentioned among the qualities that a good design must possess. The concepts under this criterion were varied and were comprised of different aspects. Therefore in the final criteria set for good design, 'health and safety', 'ease of use', 'meeting the needs of the user', 'honesty and sincerity' and 'good value for money' were decided to be discrete criteria.

The second most emphasised criterion was respect to the environment. Measures related to minimising the harm to the environment during production, usage and disposal, economic usage of natural resources, and energy-saving were emphasised in this respect. One of the respondents mentioned that the producer, the marketer and the designer should handle the wide-ranging subject of sustainability collectively. Another respondent declared that designers are one of the stakeholders who have a considerable negative effect on the environment and that the designer has the power to turn this into a positive effect by influencing the producer and the user. 
The third most highlighted criterion was novelty and innovation. Concepts such as originality, creativity, and originality in problem identification and solution were rated highest among the related concepts. Three respondents especially mentioned that innovation should not be restricted to technological innovation or invention: innovation can be rooted in design, whilst technological innovation can acquire use value by design.

Other frequently mentioned criteria were functionality, production quality, aesthetics, contribution to brand awareness, and good usage of national resources.

In answering the first question, a number of respondents declared that some of these criteria are so essential that they should not even be considered as evaluation criteria, but rather they should be used as prerequisites in the assessment system, such as: originality, performing the offered function without introducing any problem, and health and safety. They suggested that products should be checked in relation to these conditions, prior to the evaluation, and that products not fulfilling these conditions should be eliminated.

To achieve superiority in design, the most frequently mentioned criteria were either related to long-term macro-level benefits to society, the nation and the environment, or development of enhanced user interaction. The highlighted concepts were: empowering the user (making the user productive and independent), accessibility by everyone, offering cultural content, innovation, raising the user's awareness about the rate of energy consumption, raising society's taste, offering aesthetical pleasure, creating economic value, and developing brand identity.

The most frequently mentioned criteria that should not be taken into account in evaluating good design were mainly related to marketing aspects of products. Being parallel with current trends was rejected by a considerable number of respondents, defending the idea that a good design should create trends rather than just following them. Sales-centred criteria were rejected, such as having a high profit margin, market share, and sales success; because a product possessing such qualities may not necessarily be a good design and a firm investing on design usually receives its benefits in the longer term. The award scheme should therefore focus on the benefits that a product brings to the user, environment and the society. Having a high profit margin should not be encouraged and may cause unethical conduct. Conforming with standards was also found inappropriate as a good design criterion, since for certain product groups it is an obligatory condition that should not differentiate a product's design.

\section{DESIGN OF THE DESIGN TURKEY AWARD SCHEME}

The name, application rules, product classification and awarding process of the selection system, as well as the evaluation criteria, were defined for implementation in the first round of the awards in 2008, by taking into account the opinions of the advisory committee. The award scheme invited applications for products that were manufactured by industrial methods and launched in the market within the past three years. Furthermore, either the designer, manufacturer or trademark owner were required to be of Turkish citizenship. Applications were made online.

A two-staged evaluation process was adopted, involving a pre-evaluation followed by a main evaluation. A total of 30 jurors were invited from 


\begin{tabular}{|c|c|c|c|c|c|c|c|c|c|}
\hline \multicolumn{2}{|c|}{ weak } & \multicolumn{2}{c|}{ below average } & \multicolumn{2}{c|}{ average } & \multicolumn{2}{c|}{ good } & \multicolumn{2}{c|}{ very good } \\
\hline 1 & 2 & 3 & 4 & 5 & 6 & 7 & 8 & 9 & 10 \\
\hline
\end{tabular}

Table 2. Design Turkey 2008 good design evaluation scale (Design Turkey 2008).

Table 3. Design Turkey 2008 Good Design and Superior Design evaluation criteria (Adapted from Design Turkey, 2008).
Turkey and abroad, possessing design expertise and know-how on production, marketing, consumer affairs and current products. The jurors were recognized in professional and/or academic fields by their national and/or international works. For the main evaluation, the jurors were distributed into six individual juries consisting of five jurors, with responsibility to evaluate entries across the 12 product sectors used for the awards scheme. For the pre-evaluation, the jury evaluated the entries on the Internet, by voting according to suitability to the scope of the award application requirements and an originality criterion. Applications that passed the pre-evaluation stage were invited to the Design Turkey exhibition. The main evaluation process was carried out on the exhibited products one day before the awards ceremony. It consisted of two stages: 'good design' evaluation and 'superior design' evaluation. For the good design evaluation, the jurors graded exhibited products with a maximum

\section{Good Design Criteria}

1. Novelty and distinctiveness: The qualities that differentiate a design from its rivals: originality and distinctiveness

2. Functionality: To perform the basic product function correctly without introducing problems

3. Meeting the needs of the user: Appropriateness of the design to meeting a targeted need and the degree to which the need is answered

4. Honesty and sincerity: To realize the promised function and performance; to reflect correctly the function and qualifications of the product to the user through visual language and form

5. Aesthetics: The extent to which aesthetic qualities support and enhance the product: to sustain a visual unity, to achieve aesthetic qualities in different situations (e.g. on-off, front-view / side-view, static/ dynamic), and to create an attractive and appealing effect

6. Ease of use: To respect the user's effort and time: functional specifications that are easily understood and usable, offering physical and psychological comfort

7. Health and safety: Not to harm the user's health, to be precautious towards accidents, and to comply with relevant standards regarding health and safety

8. Economy: The appropriateness of product life span and price in comparison with the value and benefit provided to the user; to provide economical and efficient use

9. Design quality for manufacture: Well-executed design details to obtain high-quality manufacture.

10. Environmental effects: To sensitively consider factors including recycling, life span, energy consumption, economic use of natural resources and waste creation during product manufacture, use and disposal; to take necessary precautions to minimize negative effects to the environment attributable to the product

\section{Superior Design Criteria}

1. Innovation: Radical change in a product rather than just simple differentiation; the usage of new technologies, processes and methods with ingenuity and exceptional design skills; discovering new problem areas and bringing radical and positive reform to its intended users lives with the design solution

2. Functional superiority: Offering high-level functionality that is practical and easily understood by users

3. Aesthetic superiority: Remarkable aesthetic qualities which can upgrade society's taste; possessing high visual quality which is beyond the age

4. Sensitivity to the users: Enhancing functionality and usability of the product to provide superior qualities of building new interactions with the user and for making the user independent, productive and powerful; adopting universal design principles: accessibility and usability by disadvantaged user groups including the aged or people with disabilities

5. Contribution to the development of industry: Playing a pioneering role in the development of local industry and providing opportunities for new industries and employment

6. Contribution to the work environment and brand: Having potential to strengthen the brand image and to form brand identity; creating potential for export and possessing trendsetting qualities

7. Adding significant value to society's culture and identity: Contributing to the formation of design identity particularly for Turkey, adding value to this identity; being sensitive to the cultural habits of target users; offering new and economical opportunities to low income groups

8. Notable environmental merit: Making good use of natural and economical resources; implementing sustainable design principles 
of 10 points (Table 2) for each of the 10 good design criteria listed in Table 3. When the average grades of all jurors were processed, a total grade out of 100 was obtained. Those products that received a grade above 70 were deemed to have met the criteria necessary to receive a Good Design Award. However, at their discretion jurors were able to adjust this default threshold (Design Turkey, 2008).

Superior design evaluation was carried out in the second stage of the evaluation, among those products already determined as 'good designs'. Superior design criteria were grouped under eight headings, as listed in Table 3.

In order for a design to receive a Superior Design Award, it had to fulfil at least one superior design criterion. Jurors, considering the total grade that the design received in the previous stage, discussed each design in relation to the superior design criteria and reached a consensus for recommending a Superior Design Award. In 2008, a third category was also offered, in which a "TURQUALITY Design Award" was given to the most outstanding four designs by the votes of all jurors among those products already determined as 'superior designs'. In order to fit with the TURQUALITY branding promotion programme, only products holding a Turkish brand were eligible for this award. Partly because of this limitation, and partly to simplify the process, the TURQUALITY Design Award was excluded from the 2010 scheme.

After the first implementation of the award scheme in 2008, the jurors were asked about their opinions for the development of the scheme. The general opinion of the jurors was that the scheme needed to be simplified. Based upon their suggestions, ETMK slightly revised the evaluation process and criteria. The number of criteria was reduced. Since the criteria 'functionality', 'meeting the needs of the user' and 'ease of use' were close to each other in terms of scope and meaning, they were merged with the revised name 'functionality and ease of use' for Design Turkey 2010. The name of the criterion 'environmental effects' was changed to

1. Packaging: All types of packaging of goods used for the purposes of transportation, protection and presentation to consumers and the graphics related with the packaging.

2. Lighting: Indoor and outdoor lighting equipment, pocket lamps.

3. Electronic equipment: Electronic consumer goods, audio-visual devices, computers and related equipment, communication devices.

4. Electrical household devices: electrical tools and devices for cooking and cooling food and washing and cleaning purposes at home: white goods and electrical household equipment.

5. Home and office devices and accessories: Devices and tools for cleaning, cooking utensils, tableware, office accessories and stationery.

6. Public and commercial products: Urban furniture (excluding lighting), display and point of sale products and systems.

7. Home furniture: Home furniture and furniture accessories.

8. Office furniture: Office furniture and furniture accessories.

9. Sports, hobby, game, and personal products: Devices used for sports, hobby, game, leisure or personal care activities: sports goods and devices, personal care products, musical instruments, games, toys, baby care products, functional shoes, innovative jewellery and fashion accessories.

10. Transportation: Interiors and exteriors of land, rail and water vehicles and aviation products and their accessories.

11. Building components: Components and devices used for the interior and exterior of buildings: sanitary ware, sanitary fixtures, heating devices, air conditioners, electrical fittings and related hardware.

12. Capital goods: Devices for professional purposes: industrial machinery, agricultural machinery, construction machines and tools, hand tools.

13. Medical equipment and devices: Hospital and laboratory devices, rehabilitation, patient care and medical operation appliances, prostheses. 
'sustainability'. The grading was changed from a maximum of 10 points to a maximum of 5 points. The number of product classes was increased to 13, since a division was made for the furniture category into 'home furniture' and 'office furniture' (Table 4) (Hasdogan et. al., 2012).

\section{STRONGEST ASPECTS OF AWARD WINNING DESIGNS}

With an aim to identify the strongest qualities of Design Turkey Award winning products, applicants' descriptions of their designs, as presented in their application statements and jurors' grades were analysed. The application form contained questions related to the intended goals of design, distinctive and innovative aspects, aesthetical properties, benefits for the user, preliminary research, economic contribution to the firm and the brand, and environmental aspects. Firstly, the descriptions were analysed in order to find out which aspects of designs the applicants brought forward and promoted. Secondly, the jurors' average grades concerning the good design criteria were analysed and the highest graded criteria for each design were identified. Table 4 shows the strongest qualities of designs as described by the applicants and according to jurors' grades. A total of 120 awards were given to 122 product design entries in all award categories in 2008 and 2010. (In two cases two product entries were merged and given one award). The analysis was carried out on the basis of the eight good design criteria used in 2010. Up to five strong criteria were identified for each design.

As seen in Table 5, 'aesthetics' was the most emphasised criterion of the awarded designs by the applicants, as well as the highest graded criterion of the designs by jurors. The applicants of $70 \%$ of awarded designs emphasised the aesthetical qualities of their designs, whilst for $60 \%$ of the awarded designs the jurors graded the aesthetical aspects high. The second most emphasised criterion of designs by the applicants was 'functionality and ease of use' $(67 \%)$, however in only $43 \%$ of the awarded designs this criterion was rated highly by jurors. 'Novelty and distinctiveness' $(49 \%)$ and 'design quality for manufacture' $(48 \%)$ were the criteria rated highly by jurors for almost half of the awarded designs. 'Novelty and distinctiveness' was the third most emphasised criterion of awarded designs by the applicants (55\%), however 'design quality for manufacture' was emphasised by only $39 \%$ of the applicants. The reason that jurors graded this criterion high, despite it not being frequently emphasised by applicants, was that it could best be judged by examining the product. In the same way, 'honesty and sincerity' was almost never $(2 \%)$ mentioned by the applicants, but was graded high for $29 \%$ of designs by the jurors, because this aspect by its nature is not usually expressed or claimed, but rather is left to be judged. The criteria 'health and safety', 'sustainability'

Table 5. Percentages of strongest aspects of Design Turkey awarded products in 2008 and 2010 according to applicants' descriptions and jurors' grading for good design criteria.

\begin{tabular}{|l|c|c|}
\hline Good Design Criteria & $\begin{array}{l}\text { applicants' } \\
\text { descriptions (\%) }\end{array}$ & $\begin{array}{l}\text { jurors' } \\
\text { grading (\%) }\end{array}$ \\
\hline Novelty and distinctiveness & 55 & 49 \\
\hline Functionality and ease of use & 67 & 43 \\
\hline Honesty and sincerity & 2 & 29 \\
\hline Aesthetics & 70 & 60 \\
\hline Health and safety & 12 & 17 \\
\hline Economy & 7 & 13 \\
\hline Design quality for manufacture & 39 & 48 \\
\hline Sustainability & 12 & 14 \\
\hline
\end{tabular}


Table 6. Number of award winning design fulfilling superior design criteria in Design Turkey Awards 2008 and 2010.
Figure 1. Superior Design Award 2010, Zula Dervish coffee cup manufactured by Porterra Porselen, designed by Kunter Şekercioğlu.

Figure 2. Superior Design Award 2010, Step Mienterra carpet, designed by Can Yalman and Korkut Tuzcu.

Figure 3. Superior Design Award 2010, Vestel UH 590 nofrost refrigerator, designed by Murat Hondu, Burçin Özkır, Halil Göksal and Vestel Beyaz ID Team.

\begin{tabular}{|l|r|}
\hline Superior Design Criteria & Designs \\
\hline Innovation & 14 \\
\hline Functional superiority & 11 \\
\hline Aesthetic superiority & 21 \\
\hline Sensibility to the users & 7 \\
\hline Contribution to the development of industry & 1 \\
\hline Contribution to the work environment and brand & 7 \\
\hline Adding significant value to society's culture and identity & 2 \\
\hline Notable environmental merit & 0 \\
\hline
\end{tabular}

and 'economy' were rarely emphasised by the applicants and rarely graded high by jurors.

A total of 34 Superior Design Awards were given in 2008 and 2010. Up to four superior design criteria were indicated by the jurors when deciding on the award. In this evaluation, parallel with the good design evaluation, aesthetical aspects of the products were valued most. As seen in Table 6, 21 designs were found aesthetically superior, whilst innovation was the second and functional superiority was the third most assigned criterion for Superior Design awarded products.

Characteristics of the award winning designs will now be discussed with reference to the Design Turkey good design criteria. For each criterion, at least one highly rated design will be given as an example.

\section{Novelty and Distinctiveness}

Novelty and distinctiveness was usually graded as a strong aspect by making reference to other strong aspects. For example, in some cases technological innovation leads a product to be distinctive in terms of visual appearance or with the new functions it provides to the user. In certain other cases, distinctiveness can be achieved solely by aesthetics. The Zula Dervish coffee cup in Figure 1 implements double layered ceramics in order to eliminate the handle, which enabled the designer to develop an iconic form referring to whirling dervishes. This made the design innovative, aesthetic and easy to use. The Mienterra carpet in Figure 2 makes use of a new technology to discover new aesthetics in carpet design. The method of three-dimensional weaving enabled the designer to create a multi-layered texture. This made it distinctive, innovative and aesthetic. The Vestel no-frost refrigerator in Figure 3 uses the whole front surface of
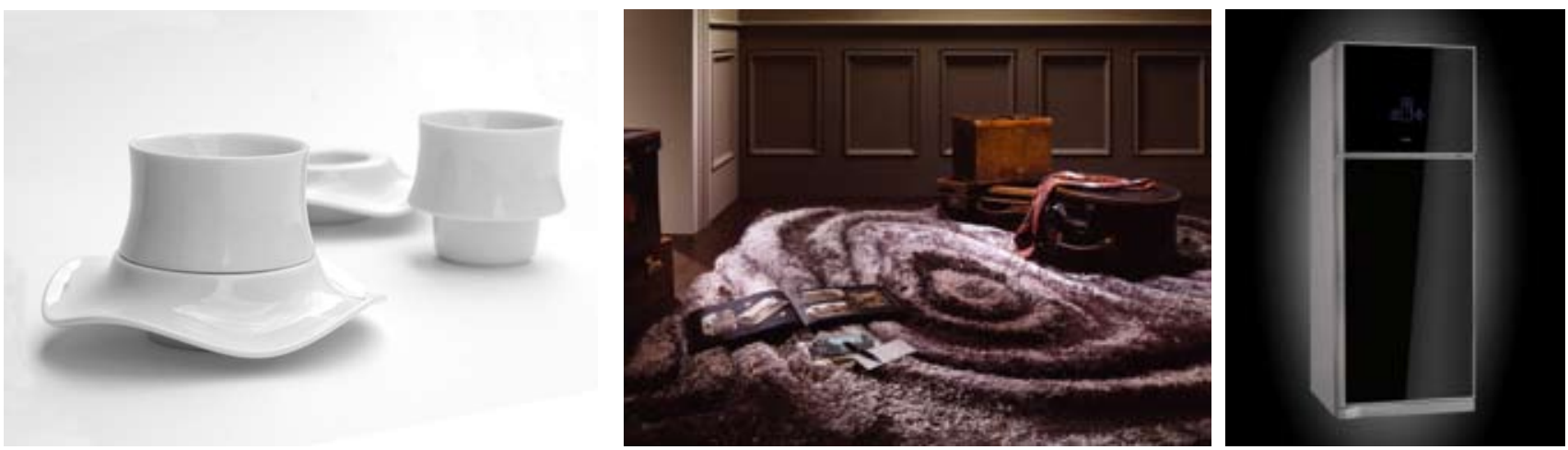


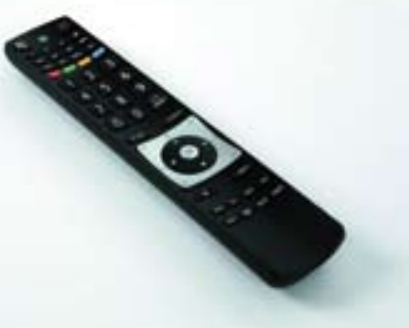

Figure 4. Superior Design Award 2010, Vestel RC 5110 remote control, designed by Burak Emre Altınordu, Ayça Kınık and Vestel ID Team.

Figure 5. Good Design Award 2010, Otokar Kent 290 lf (low-floor) transportation bus, designed by Arzu Hüsniye Toker Özkurt, Haluk Özel, Bülent Özkurt, Erhan Kaynak, Kayhan Kaya and İsmail Tepebaşı.

Figure 6. Good Design Award 2010 Karel NT10D telephone, designed by Nurtan Meral and Tahsin Çetinoğlu.

Figure 7. Superior Design Award 2010, Çebi Joy Collection furniture accessories, designed by Sevin Coşkun and Mustafa Emre Olur.

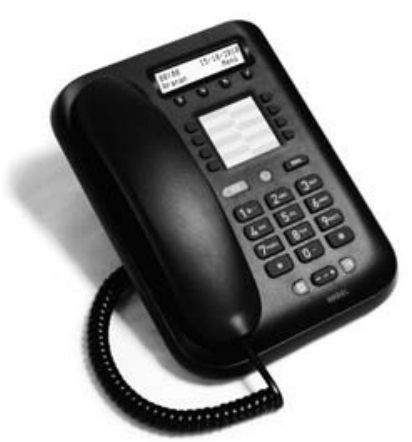

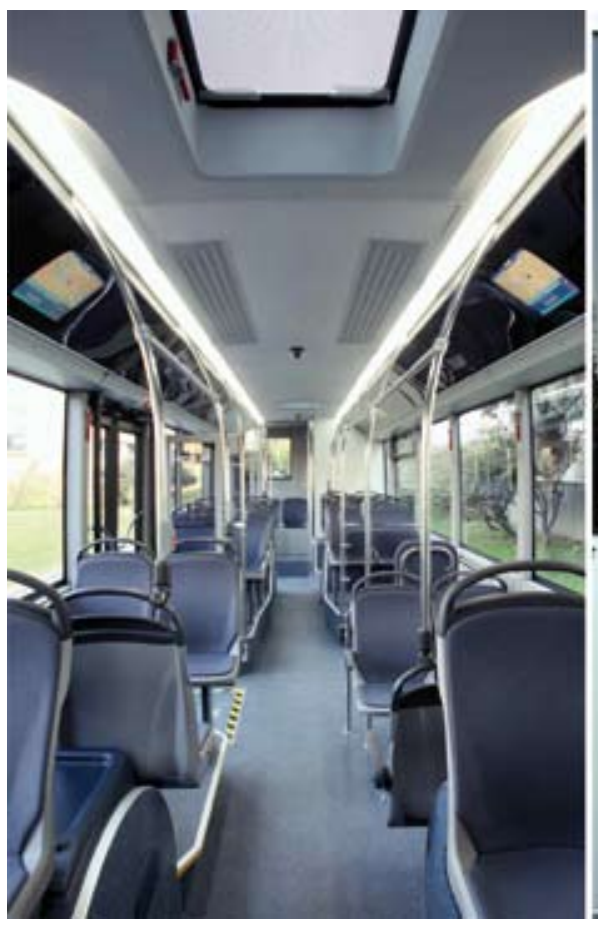

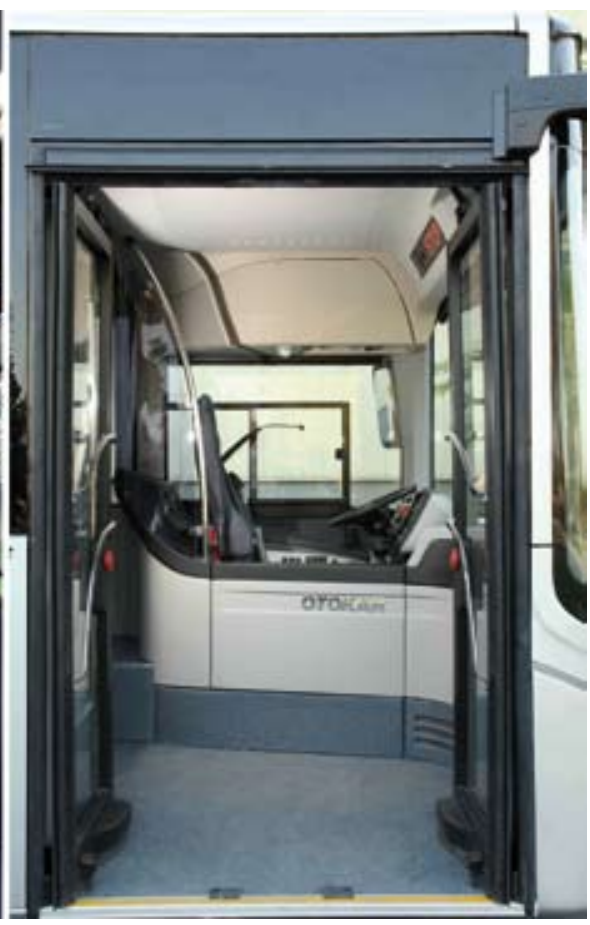

the door as a touch sensitive screen offering functions of an mp3 player, voice messaging, timer and reminder, making the product distinctive, aesthetic, functional and possessing high quality design details.

\section{Functionality and Ease of Use}

Functionality and ease of use was emphasised as a strong quality by all applicants of electrical household devices, transportation, medical equipment and capital goods. However, apart from applications in transportation, jurors did not always grade applications highly with regard to functionality and ease of use. This might be because this criterion is a key factor in these sectors and for this reason the jury was more critical. Some successful examples were the remote control in Figure 4 targeting elderly people with larger controls and which also provided a delightful usage. The inner city bus in Figure 5 provides easy boarding and alighting for elderly and disabled passengers with its stepless structure and folding

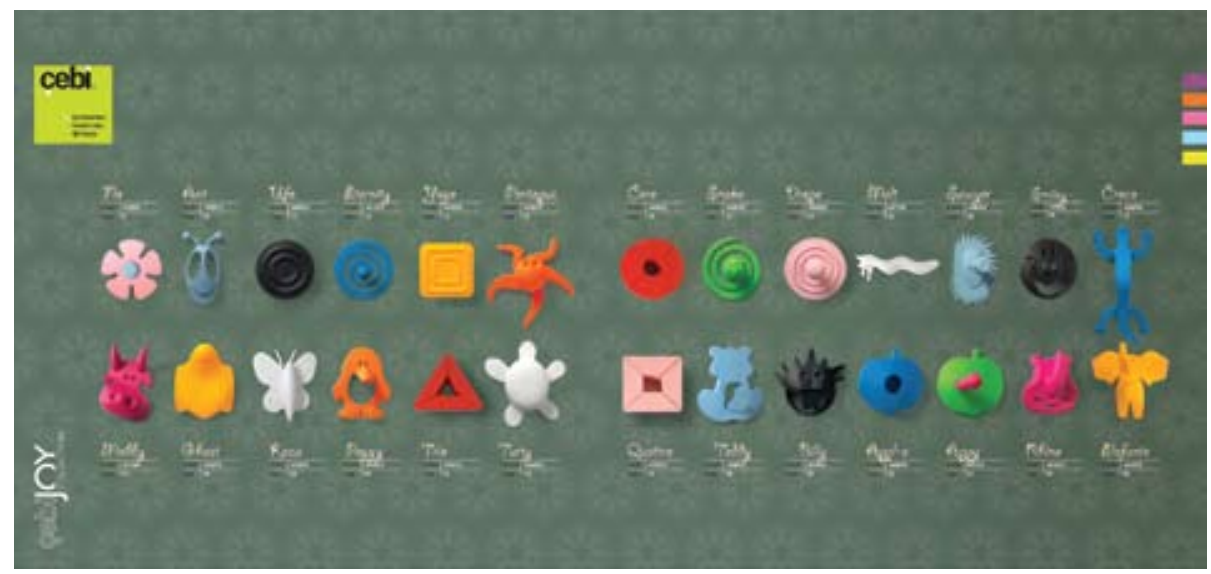


ramp, whilst providing easier travel for the visually impaired via Braille script notifications.

\section{Honesty and Sincerity}

Honesty and sincerity was graded high especially for products that possessed other strong aspects and at the same time communicated their values in a good, simple and direct way. For example, the Karel telephone in Figure 6, possesses all the functions of other telephones, but is the most affordable and has a simple interface and form that makes it easy to use. Another example is the furniture accessories for kids in Figure 7, which are affordable and appeal to their target user in a joyful and humorous way.

\section{Aesthetics}

Aesthetics was graded high especially in packaging, furniture and home and office devices and accessories. Aesthetics was emphasized as a strong factor by almost all of the applicants to the furniture category. An example for the furniture category is To Berjer in Figure 8, which enables the user to alter the aesthetics of the product by changing its alternative types of 'clothes'. For home and office devices and accessories, the Zula Dervish coffee cup previously shown in Figure 1 is a good example. A good example for packaging is the Binbirçiçek honey jar in Figure 9, which has figures of nature such as the honeycomb and bees as an in-mould decoration and encourages the user to use the same jar for serving and for storage as a second use. In these product sectors, aesthetics play a key role. On the other hand, aesthetics may become an important factor in sectors

Figure 8. Superior Design Award 2010, Birim To Berjer seating, designed by Tanju Özelgin and Ayça Çakanışık.
Figure 9. Superior Design Award 2010, Binbirçiçek honey jar, manufactured by Anadolu Cam, designed by Oya Akman for Altıparmak Gida.
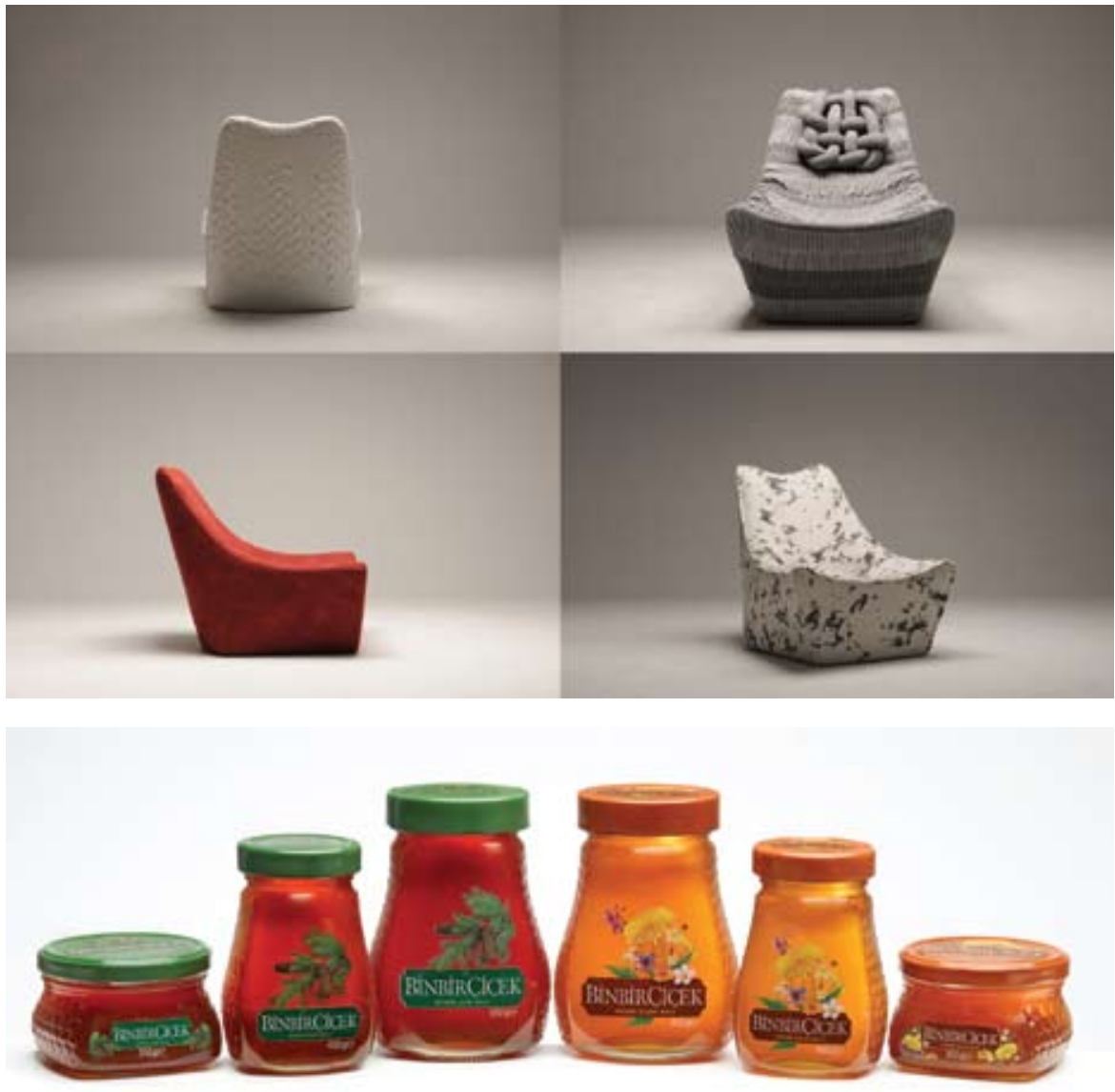
Figure 10. TURQUALITY Design Award 2008, Tautmann patient transfer trolley, manufactured by KBB and designed by Mehmet Ataman, Stefan Lippert, Özkan Işık and Wolf Giebel.
Figure 11. Good Design Award 2010, Hidromek GEN Series excavator, designed by Hidromek StilStüdyo, Hakan Telıșı, Zeliha Uyurca, Okay Gökel, Sevilay Turgut, Mustafa Hilmi Gökçe, Müslüm Ersoy and Abdullah Çömek.
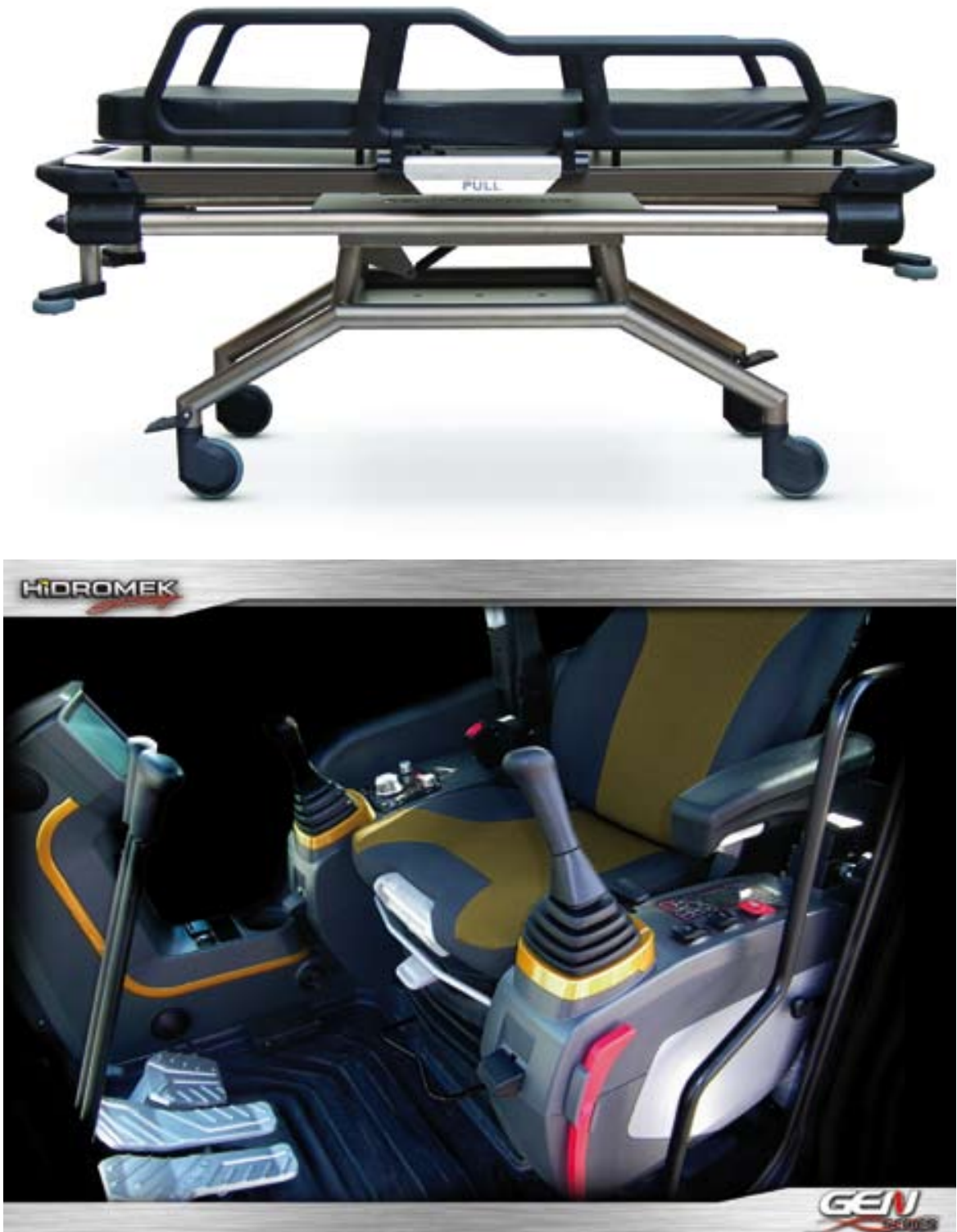

where it is less prominently considered, such as medical products and capital goods. For example, the Tautmann patient transfer trolley in Figure 10, which enables a patient to be transferred from one trolley to another safely and hygienically, was found aesthetically superior by jurors, besides its high functionality. Another example is the Hidromek GEN series excavator in Figure 11. Besides its ergonomically designed interiors, it was graded high by jurors due to its visual unity, dynamic forms and colour options.

\section{Health and Safety}

Apart from medical products, health and safety was rarely considered and valued as a strong aspect for awarded designs. For certain products where safety or hygiene is a problematic issue this criterion was a starting point. Especially for Turkish teapots, for which scalding accidents can happen, products which offer a solution to this problem were graded high for health and safety. In Figures 12 and 13, both teapots provide a steam 

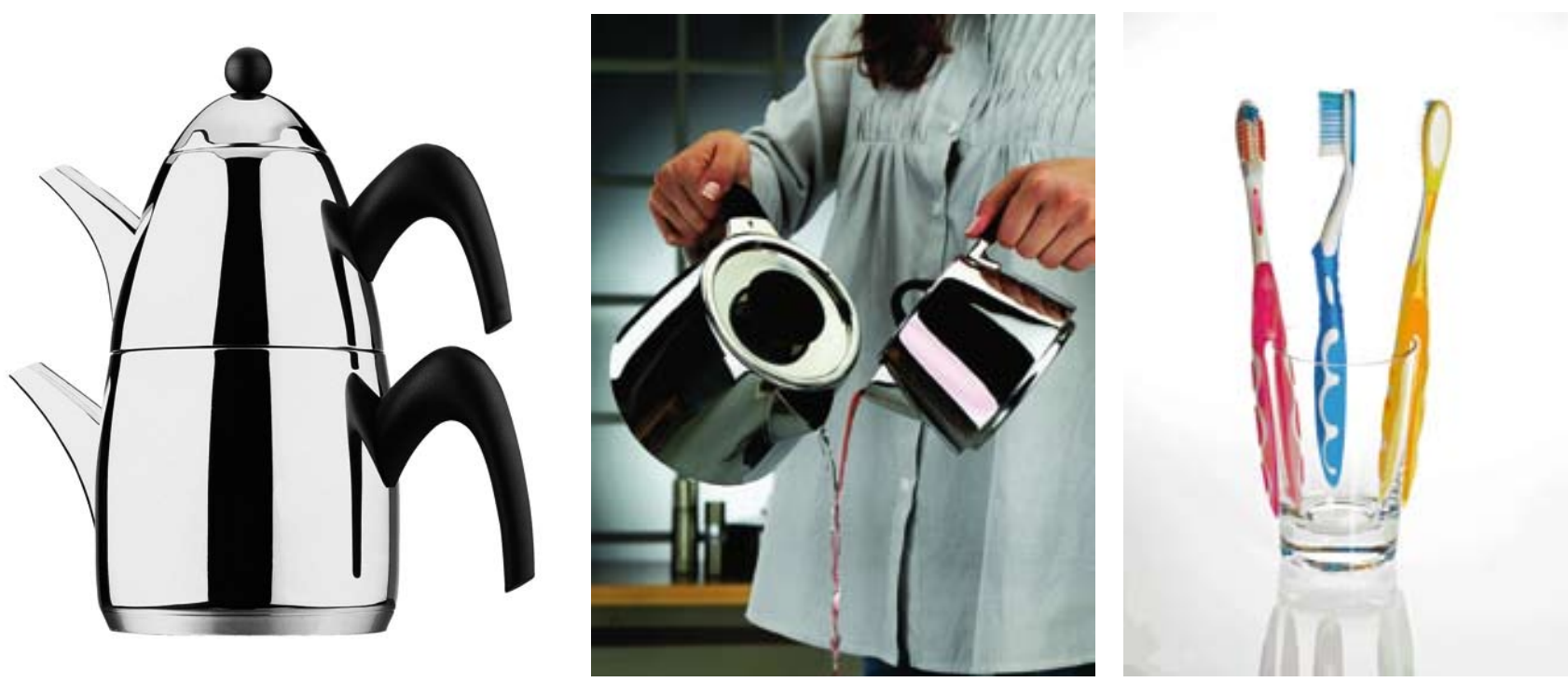

Figure 12. TURQUALITY Design Award 2008, Jumbo teapot set, designed by Minas Çolakyan.

Figure 13. Good Design Award 2010, Korkmaz Esta kettle, designed by Kerim Korkmaz.

Figure 14. Good Design Award 2010, Banat Acrobat toothbrush, designed by Kunter Şekercioğlu and Özüm Özkan.
Figure 15. Superior Design Award 2010, Arnica Bora vacuum cleaner, manufactured by Senur, designed by Yasemin Ulukan.

Figure 16. Good Design Award 2010, Aysan ESL energy saving lamps, designed by Mehmet Remzi Cumalı. shield between the kettle and the brewing pot, the lids are prevented from dropping off, and the form prevents the product from tipping over. For toothbrushes, hygiene is a crucial problem. The split body form of the Banat Acrobat toothbrush in Figure 14 enables the toothbrush to be fixed alongside the rim of the toothbrush holder. This feature prevents potential germ transfer between toothbrushes. Also the vacuum cleaner in Figure 15, owing to its removable tank and easily cleanable parts, was valued high in terms of health and safety.

\section{Economy}

Economy has been a strong factor in relation to two different aspects. Certain products, besides possessing a considerable number of merits, are at the same time affordable, such as the furniture accessories for kids in Figure 7, and the Arnica Bora vacuum cleaner in Figure 15. Bora's production cost was decreased because its parts were designed to be assembled quickly with a minimum error rate. Another aspect of economy concerned products providing economic usage. For example, the Aysan energy-saving lamp with changeable tube and base (Figure 16) enables the user to reuse the ballast for many years and allows use of different types of lamp holders within the same system.
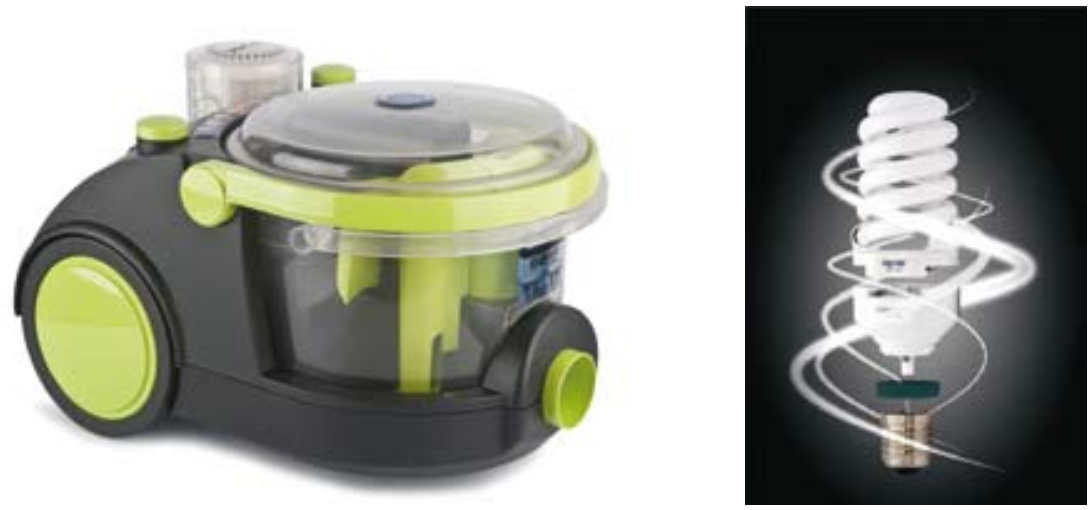
Figure 17. Superior Design Award 2010, Ersa Frame executive work table series, designed by Ece Selamoğlu Yalım, M. Oğuz Yalım, Feride Toprak and Ece Yalım Design Studio.

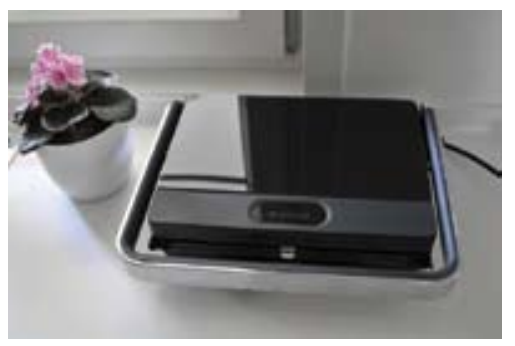

Figure 18. Superior Design Award 2010, Arçelik K2369 Tost Gril panini maker, designed by Ümit Altun and DesignUM Design Team.
Figure 19. Good Design Award 2008, Step Pen Bio-pen, designed by Ümit Altun, Uğraş Akpinar and DesignUM Design Team.

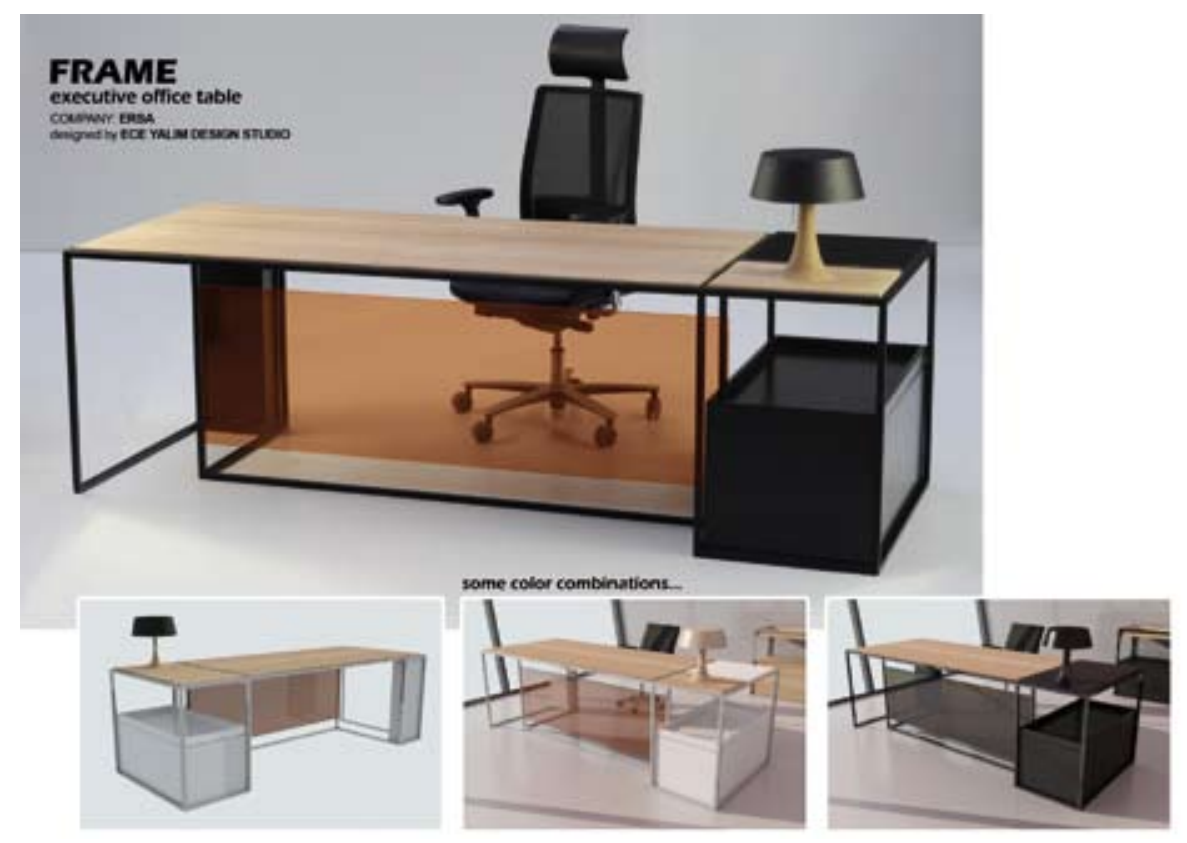

\section{Design Quality for Manufacture}

Jurors graded design quality for manufacture highly for products that had other strong aspects. For example, the Ersa Frame executive work table series in Figure $\mathbf{1 7}$ gives the impression of being hand-crafted and has a modularity concept based on personalisation, offering optional pieces and various colour combinations that enhance its aesthetic qualities and make it an innovative product. The tactile qualities of the Arçelik panini maker (Figure 18) are enhanced by the changeable materials on its upper surface, whilst the innovation in its hinge mechanism adds functionality to its usage.

\section{Sustainability}

Sustainability was rarely used as a starting point in design by the applicants of award winning products. A notable example was the Step Bio-Pen shown in Figure 19, produced from degradable bio-plastic, which also contains three Black Pine seeds. Another example is the Taç Freemood quilt cover set packaging in Figure 20. The natural coloured aluminium

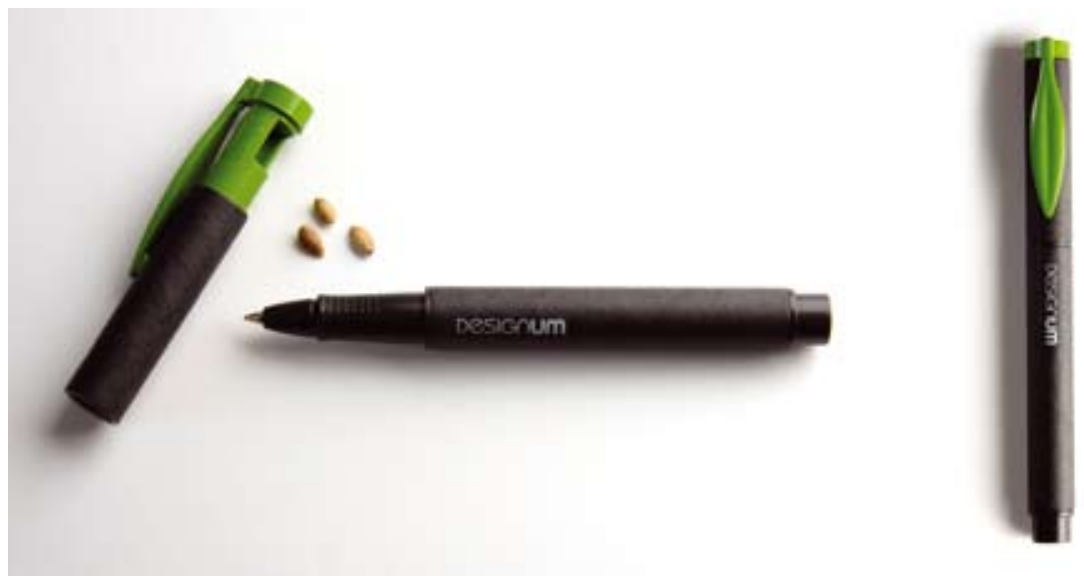


Figure 20. Superior Design Award 2010, Taç Freemood packaging design, designed by Orhan Irmak and Bürkan Çiftçigüzeli.

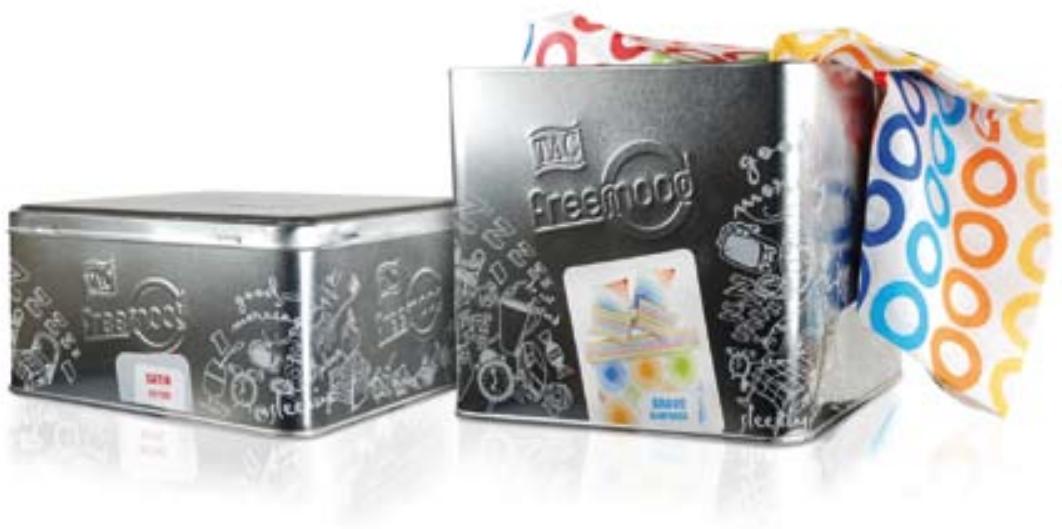

cubical box looks as if it is unbranded and offers secondary use scenarios to its user. Products created with an aim to consume less energy were also deemed to be sustainable by the jurors, such as the Aysan light bulb shown in Figure 16.

\section{CONCLUSIONS}

Early examples of national design award schemes based on good design evaluation had a common aim to regulate society's taste and educate the public about the merits of good design. They were criticised with their top-down approach. Their criteria set, based on modernistic ideals, were evolved through the transition period from modernism to postmodernism. Products considered for these early awards were evaluated in isolation from their intended users and environments. The evaluation lacked the necessary focus on user interaction and the potential effects of the products on the environment. In more recent developments in design awards, sensitivity to users and sustainability have become prominent new criteria, being added to the existing set comprised largely of attractiveness, efficiency and production quality.

Design Turkey Industrial Design Awards was set up with a similar aim, to create awareness in society and industry about good design. Its criteria set was determined by consulting the opinions of design experts, scholars and professionals in Turkey. In this way, Design Turkey has an underlying aim to reflect the ideals of the Turkish industrial design community, whilst of course being informed by the criteria for 'good design' published by other international award schemes. In other words, Design Turkey was intentionally configured for designerly evaluation, but at the same time limitations may exist in reflecting the dynamics of consumption and public taste.

In line with contemporary developments in the evaluation criteria of design award schemes, experts of the Turkish design community prioritised sensitivity to users and sustainability among the criteria that a good design must possess. On the other hand, the strongest aspect of award-winning designs from the Design Turkey Industrial Design Awards was aesthetics, both in applicants' product descriptions and jurors' evaluation reports.

There are no clear borders between the concepts underlying design criteria. Certain strengths of a product may lead to other strengths touching upon 
related criteria. For example, being innovative or distinctive can be a result of being different in aesthetics or being unusual in the functions offered to users. Similarly, the concept of economic usage is related with sustainability. Being aesthetically pleasing may provide delightful use and thus affect ease of use. Therefore, what can be observed is that awardwinning designs were usually strong across a variety of interlinked criteria, rather than a single aspect.

A product's strongest design attribute is usually closely linked to its main idea or reason for conception. In this respect, it was notable that criteria such as health and safety, sustainability, and economy were rarely mentioned and valued as strong aspects of award-winning designs, because they are rarely the starting point of a design idea. An exception, for example, is the case of Turkish teapots, where the starting point was health and safety. In applicants' product descriptions, health and safety and sustainability issues were usually mentioned as conforming with certain norms or standards. Since applicants did not mention these aspects as strongly part of their designs, jurors were not inclined to grade highly in criteria related to these aspects.

The experts, scholars and professionals of the Turkish industrial design community presented their idealistic views about how design practice and the quality of design products should progress. In this sense, their ideals about being sensitive to users and the environment have so far not matched closely with the assessed strengths and characteristics of award-winning designs. The strongest aspect of evaluated designs was their aesthetical qualities: this is not surprising, since aesthetics is the essence of the field of design. It is the aesthetical aspect that draws people's attention to industrial designs, and which differentiates from engineering related qualities such as efficiency and performance. Even if the main concept for a new design is not closely linked with aesthetics, the resulting product is nevertheless expected to possess a refined level of aesthetical quality.

The profile of sustainability needs to be raised as a criterion since it was not generally mentioned by the applicants as a strong aspect of their design, despite its growing importance, nor it was evaluated high by the jurors. Awareness of applicants can be raised in future rounds of the award scheme, by explaining different dimensions of sustainability during the application process, which may in turn invite manufacturers' attention.

The highest discrepancy between the applicants' descriptions and jurors' evaluations concerned functionality and ease of use. Although awardwinning designs claimed to elevate functional benefits for users, they could not meet the expectations of jurors. Especially in relation to certain product types, such as electronic household products and electronics, which require intense user interaction, future rounds of the Design Turkey scheme must place greater attention to functionality and ease of use. On one hand, the applicants should be given the opportunity to demonstrate the interactive qualities of products, on the other hand jurors should be able to 'try out' the products as if in a real usage scenario. Such new practicalities in the scheme may encourage the development of interactive qualities of applicant products.

Design Turkey industrial Design Awards indicated directions for the development of Turkish industrial design, as well as providing insights for the improvement of evaluation criteria of the award schemes in general. 


\section{REFERENCES}

BUCHANAN, R. (2000) Good Design in The Digital Age, AIGA Journal of Design for the Network Economy, (1:1) 1-4.

BURALL, P. (1997) The Official Critic- Irrelevant or Influential?, Design Issues, (13:2) 36-39.

DESIGN TURKEY (2008) Design Turkey Industrial Design Awards Evaluation Guide 2008, guide distributed to jurors, October 2008, İstanbul.

DESIGN TURKEY (2010) Turkey Industrial Design Awards Evaluation Guide 2010, guide distributed to jurors, December 2010, İstanbul.

DESIGN TURKEY INTRANET (2011) Design Turkey, online, available at: www.designturkey.org.tr accessed 11.03.2011.

ETMK (2006) ETMK İyi Tasarım Değerlendirme Sistemi, Proje Danı̧̧ma Kurulu 1. Ankete Verilen Cevaplar, report sent to the advisory committee, ETMK Headquarters, December 2006.

ETMK (2007) ETMK İyi Tasarım Değerlendirme Sistemi, Proje Danışma Kurulu II. Ankete Verilen Cevaplar, report sent to the advisory committee, ETMK Headquarters, February 2007.

ETMK (2008) Industrial Designers Society of Turkey, information booklet, ETMK, Ankara.

iF DESIGN AWARDS (2011) International Forum Design Honnover, online, available at: http://www.ifdesign.de/index e accessed: 11.03.2011.

JIDPO (2008) Good Design Awards, online, available at:

http:// www.g-mark.org/english/aginfo/index.html accessed: 01.032008.

HAYWARD, S. (1998) 'Good Design Is Largely a Matter of Common Sense': Questioning the Meaning and Ownership of a Twentieth-Century Orthodoxy, Journal of Design History (11:3) 217-33.

HASDOĞAN, G., DALAMAN, B., ERSAYIN S. (2012) Award Winning Designs: Design Turkey 2010 Industrial Design Awards, TR Ministry of Economy, Turkish Exporters Assembly, Industrial Designers Society of Turkey, Ankara.

HASDOĞAN, G. (2006) Good Design Award Scheme, letter to members and experts, 29 October 2006.

HASDOĞAN, G. (2009) The Institutionalization of the Industrial Design Profession in Turkey: Case Study- The Industrial Designers' Society of Turkey, The Design Journal, (12:3) 311-38.

KAYGAN, H. (2006) Evaluation of Products Through the Concept of National Design: A Case Study on Art Decor Magazine, Unpublished Master Thesis, Middle East Technical University, Department of Industrial Design.

LUCIE-SMITH, E. (1983) A History of Industrial Design, Phaidon, Oxford.

RED DOT WEBSITE (2011) Red Dot Online, avalilable at: http:/ / en.reddot.org/ accessed: 11.03.2011.

SPARKE, P. (2004) An Introduction to Design and Culture: 1900 to the present, Routledge, Oxon. 
Alındı: 12.10.2011; Son Metin: 27.03.2012

Anahtar Sözcükler: iyi tasarım ödülleri; Türk tasarımı; Türkiye'de tasarım; endüstriyel tasarım değerlendirme ölçütleri.
SUNG, W.O., CHUNG K., NAM K. (2009) Reflections on Design Excellence through International Product Design Award Schemes, The Design Journal (12:2) 171-94.

WOODHAM, J. (2004) Good Design. A Dictionary of Modern Design. Oxford University Press, Oxford Reference Online, available at: http:/ / www.oxfordreference.com/views/ENTRY. html?subview=Main\&entry=t160.e369 accessed 28.02.2011.

\section{IYYI TASARIM ÖLÇÜTLERİ ÜZERİNDEN TÜRK TASARIMINI NITTELENDİRMEK: 'DESIGN TURKEY' ENDÜSTRIYYEL TASARIM ÖDÜLLERİ ÜZERİNE ÖRNEK ÇALIŞMA}

İyi tasarım ödülleri, bir ülkenin ürünlerini küresel pazarda tanıtmak ve değerlerini yükseltmek için etkili bir araçtır. Ödüller, iyi niteliklere sahip ürün tasarımlarının taşıdığı değerleri tanıtarak toplumun ve endüstrinin tasarım farkındalığını yükseltmeyi amaçlar. Böylelikle ödül kazanan tasarımlar bir ülkenin tasarımlarının nitelikleri, özellikleri ve tasarıma ilişkin idealleri hakkında iyi bir gösterge olabilir. Design Turkey Endüstriyel Tasarım Ödülleri, ilki 2008 yılında düzenlenen, iki yılda bir tekrar eden devlet destekli ulusal bir ödül sistemidir. Bu makalenin yazarı, Türkiye' de endüstriyel tasarım alanından akademisyen, profesyonel ve uzmanlara danışarak ödül sisteminin geliştirilme sürecini yürütmüş ve değerlendirme sürecini koordine etmiştir. Bu makale, Design Turkey Endüstriyel Tasarım Ödüllerini kazanan ürün tasarımlarının özelliklerini ödül sisteminin değerlendirme ölçütleri üzerinden araştırmayı amaçlamaktadır. Makale, dünyaca bilinen endüstriyel tasarım ödülleri kapsamında, "iyi tasarım" kavramının köken ve gelişimine yönelik genel bir tarihçe vererek başlamaktadır. Daha sonra, Design Turkey Endüstriyel Tasarım Ödüllerinin değerlendirme ölçütlerinin geliştirilme süreci, Türkiye'de endüstriyel tasarım alanından uzmanların görüşleri üzerinden anlatılmaktadır. Ödül kazanan tasarımların başvuru sahiplerinin tasarımlarını tanımlarken kullandıkları ifadeler ve jüri üyelerinin tasarımlar hakkında çeşitli ölçütler üzerinden yaptıkları değerlendirmeler analiz edilmiştir. Ödül kazanan tasarımların özellikleri iyi tasarım ölçütleri üzerinden tanımlanmıştır. Son olarak ödül kazanan tasarımların güçlü yanlarının Türkiye' deki endüstriyel tasarım uzmanlarının idealleri ile ne ölçüde örtüştüğü tartışılmıştır.

GÜLAY HASDOĞAN; B.ID, MS in BS, Ph.D.

Received her Bachelor of Industrial Design and MSc in Building Science degrees from Middle East Technical University (METU), and her PhD from Central Saint Martin's College of Art and Design, London. Served as President of the Industrial Designers Society of Turkey. Currently Associate Professor and Chairperson of the Department of Industrial Design at METU. 